\title{
EXCESSIVE DAYTIME SLEEPINESS OF THE BRAZILIAN EMPEROR DOM PEDRO II PROBABLY DUE TO SLEEP APNEA SYNDROME
}

\author{
Rubens Reimão', Marleide da Mota Gomes², Péricles Maranhão-Filho
}

\begin{abstract}
Objective: To show that the obstructive sleep apnea syndrome (OSAS) was the probable cause of D. Pedro Il's excessive daytime sleepiness. Method: Research of historical documents and bibliographical. Results: The excessive daytime sleepiness of D. Pedro II (1825-1891) was well known and bitterly criticized behavior by oppositionist magazines; it was also recognized by his peers. He would fall asleep in public places such as the theater and while attending lectures. As a youth, he was of normal complexion, putting on weight (obesity) at middle years. Conclusion: The possibility of this diagnosis is particularly relevant in this case because it points to an organic cause for D. Pedro II daytime naps and excessive daytime sleepiness. It could be the result of OSAS and not "disinterest" as erroneously assumed at that time.
\end{abstract}

KEY WORDS: sleep, sleep disorders, sleep apnea, history of neurology, D. Pedro II.

\begin{abstract}
Sonolência diurna excessiva de Dom Pedro II do Brasil devida provavelmente à síndrome de apnéia do sono
Resumo - Objetivo: Evidenciar a síndrome de apnéia do sono tipo obstrutivo (SASO) como provável causa da sonolência diurna excessiva de D. Pedro II. Método: Pesquisa de documentos históricos e bibliográfica. Resultados: A sonolência diurna excessiva de D. Pedro II (1825-1891) era bem conhecida e criticada enfaticamente pelas revistas oposicionistas, era também reconhecida pelos seus pares. Ele adormecia em lugares públicos como no teatro e ao assistir aulas. Como jovem ele tinha compleição normal, ganhando peso (obesidade) na meia idade. Conclusão: A possibilidade deste diagnóstico é particularmente relevante neste caso porque aponta para uma causa orgânica para os cochilos diurnos e a sonolência diurna excessiva. Pode se dever à SASO e não ao "desinteresse" como erroneamente admitido naquela época.
\end{abstract}

PALAVRAS-CHAVE: sono, distúrbios do sono, apnéia do sono, história da neurologia, D. Pedro II.

The excessive daytime sleepiness of Brazilian Emperor D. Pedro II (1825-1891) was a well known and bitterly criticized behavior at that time by the oppositionist magazines ${ }^{1-6}$.

It was also recognized by his peers. Objective: To show that the obstructive sleep apnea syndrome (OSAS) was the probable cause of D. Pedro II's excessive daytime sleepiness ${ }^{7-9}$.

\section{REPORT}

D. Pedro II presented excessive daytime sleepiness starting in middle age that worsened progressively ${ }^{5}$. This impaired his activities as he would fall asleep in public places such as the theater and while attending lectures (Fig 1). The humorous stories "Balas de estalo" of the Rio de Janeiro magazine Gazeta de Noticias (1883-1886) numerous times criticized the Emperor's naps:
"They said the Monarch has to have a good nap in the theater to show that he does not care at all"3. Another text in the same magazine complained that he was not able to attend conferences: "His Majesty slept deeply a whole hour long - the whole conference time".

Not only the opposition complained about D. Pedro Il's excessive daytime sleepiness; the Countess De Barral writes: "I can understand when enough time is given to sleep, but to stay this way, falling asleep while walking and sleeping standing up tires the brain and you should take better care of your health" ${ }^{2}$. In successive photos we can notice that as a youth, D. Pedro II was of normal complexion, putting on weight (obesity) at middle age (Fig 2).

D. Pedro II was evaluated regularly during his life by several Brazilian physicians headed by Cláudio Velho de Motta Maia $(1843-1897)^{10}$. Even close to his death including international-

\footnotetext{
'Division of Clinical Neurology, Hospital das Clinicas, University of São Paulo Medical School, São Paulo SP, Brazil; ${ }^{2}$ Instituto de Neurologia Deolindo Couto, Rio de Janeiro Federal University (Universidade Federal do Rio de Janeiro - UFRJ), Rio Janeiro RJ, Brasil; ${ }^{3}$ Hospital Universitário Clementino Fraga Filho, Rio de Janeiro Federal University (Universidade Federal do Rio de Janeiro - UFRJ).
}

Received 30 January 2008, received in final form 6 June 2008. Accepted 8 July 2008.

Dr. Rubens Reimão - Rua dos Bogarís 38 -04047-020 São Paulo SP - Brasil. E-mail: reimaorubensneuro@yahoo.com 
ly acclaimed physicians such as his life-long friend Jean Martin Charcot ${ }^{7}$. This left no doubt that he did not display cognitive mental deficits. He died when at the age of 66 years in exile in Paris in $1891^{7}$.

In 1887 Motta Maia and Albino Alvarenga reported that four years before the Emperor suffered from glycosuria ${ }^{7}$. He suffered from diabetes ${ }^{7}$ which at that time was a common explanation for several symptoms including fatigue and excessive daytime sleepiness. In 1887 and 1888 he developed a serious health problem ${ }^{7}$. The monarch's medical assistants called a conference with a most important Brazilian physician João Vicente Torres Homem. The physicians did not find any "functional disturbances of the nervous system" in the eminent patient ${ }^{7}$. It was recommended that he should go to Europe where he was evaluated by several medical notables including the Parisians, Bouchard, Michel Peter, Brown-Séquard and finally Charcot ${ }^{7}$. The opinion of these physicians was that the Emperor's health was satisfactory and that malaria (swamp fever) had "affected" the organism already weakened by diabetes, in addition to overwork'.

\section{DISCUSSION}

This case presents several aspects suggesting that the excessive daytime sleepiness was due to OSAS. This syndrome is the most common cause of excessive daytime sleepiness. The prevalence of OSAS is $1-2 \%$ of male adults. It occurs most frequently in males (proportion 8M: 1F); its onset is usually in middle age and it slowly progresses over the years as in the case described. Among patients with OSAS, $70 \%$ are obese, or moderately obese, as in the case described. The excessive daytime sleepiness is more often present in monotonous situations as in the theater, while reading, attending meetings and conferences. Even to-

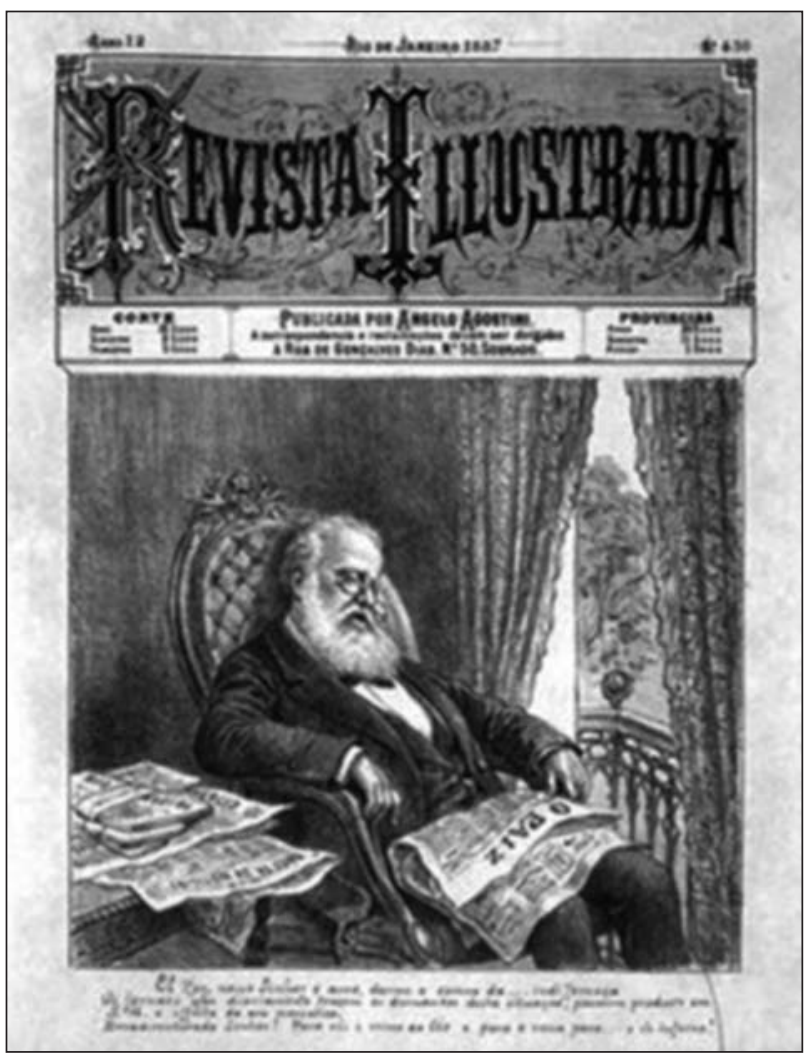

Fig 1. Revista Illustrada. Drawing of the sleepy monarch, the February $5^{\text {th }} 1987$ volume.

day, patients with excessive daytime sleepiness are often considered lazy by their families and their peers at work.

The possibility of this diagnosis is particularly relevant in this case because it points to an organic cause of $D$ Pedro Il's daytime naps and excessive daytime sleepiness.

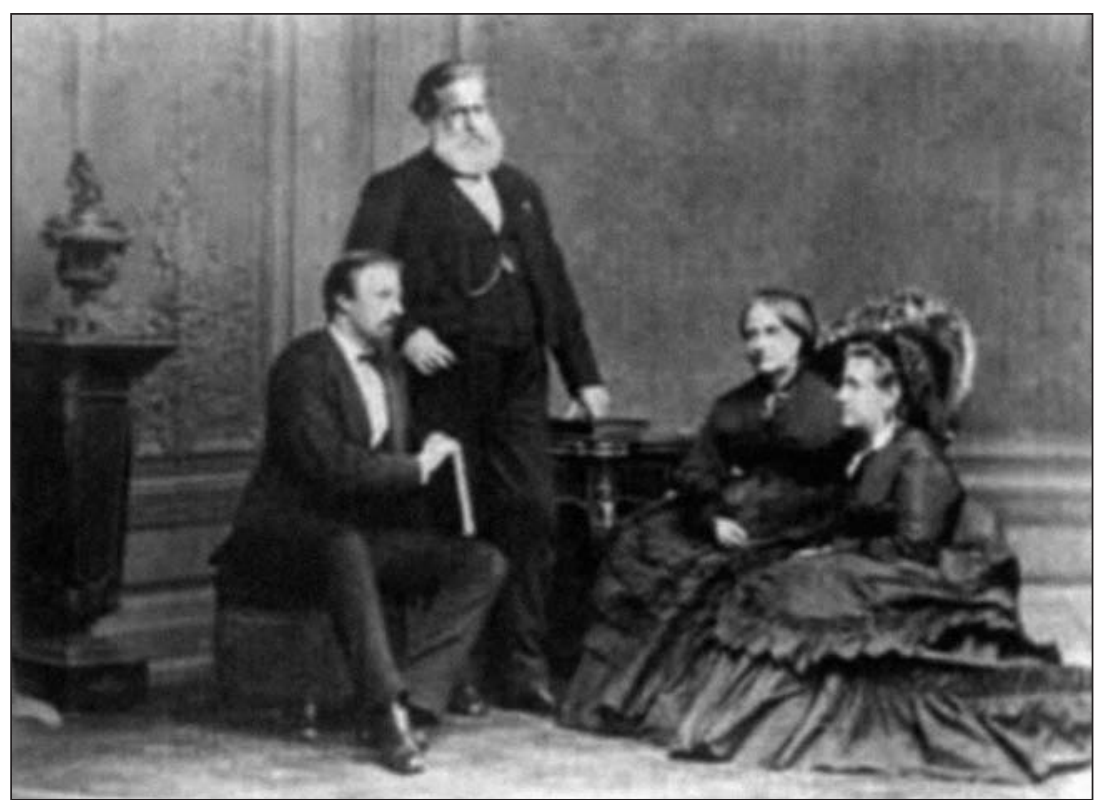

Fig 2. The family of Dom Pedro II, Emperor of Brazil. From left to right: Count d'Eu (Isabel's husband), Dom Pedro II, Teresa (his wife) and Isabel (his daughter). 
It could be the result of OSAS and not "disinterest" as erroneously assumed at that time.

As a differential diagnosis we can exclude excessive daytime sleepiness caused by narcolepsy since in narcoleptics excessive sleepiness generally starts earlier - during adolescence - and it is also accompanied by cataplexy which did not occur in this case.

We can also exclude the excessive daytime sleepiness that takes place in dementia because it is recognized that D. Pedro II did not present cognitive decline during his entire life. Also in the XIX Century and even in the first half of the XX Century diabetes was considered a common cause of excessive daytime sleepiness, which changed with the relevant development of the sleep disorders studies and mainly OSAS in the second half of the XX Century.

We should stress that OSAS was only described in the 1960 's by means of polysomnography.

\section{REFERENCES}

1. Barman RJ. Citizen Emperor: Pedro II and the making of Brazil, 18251891. Stanford: Stanford University Press, 1999.

2. Carvalho A. A Condessa De Barral. www.ihp.org.br/docs/ [acesso em 05/04/2007]

3. Mendei L. O humor das "Balas de estalo". www.cedap.assis.unesp.br/ pm2/Artgos/ [acesso em 05/04/2007]

4. Schwarz LM. As barbas do Imperador. São Paulo: Companhia das Letras, 1998.

5. Carvalho JM. D Pedro II. São Paulo: Companhia das Letras, 2007.

6. Paula SGD. Um Monarca da fuzarca. Rio de Janeiro: Relume-Dumará, 1993.

7. Gomes MM. The decline of Dom Pedro II's empire and health. Arq Neuropsiquiatr 2007; 65:1260-1265.

8. Gomes MM, Fontenelle LMC. The Emperor Dom Pedro II: his convulsive seizures when a boy. Arq Neuropsiquiatr 2007;65:1256-1259.

9. Reimão R, Gomes MM, Maranhão PF. Sonolência diurna excessiva de D. Pedro II do Brasil e o diagnóstico de apnéia do sono. In Gagliardi RJ, Reimão R, Fragoso YD (Ed). Neurologia em destaque. São Paulo: Associação Paulista de Medicina, 2007. Abstract: 631-632.

10. Mota Maia MAV. O conde de Mota Maia: médico e amigo dedicado de D. Pedro Segundo: reminiscência do segundo império. Rio de Janeiro: Livraria Francisco Alves, 1937. 